\title{
Potensi pengembangan desain produk bambu Kabupaten Sleman
}

\author{
Ismael Setiawan* \\ Program Studi Desain Interior, Institut Seni Indonesia, Yogyakarta, Indonesia
}

\begin{abstract}
The bamboo craft industry in Sleman Regency has not experienced significant growth within the last decade. Stakeholders of the industry want to synergy with academia on design development. Design development concept associated with the design process, which requires the gathering of the information about many things associated with the products so that the created designs can solve the problem of the industry. This basic research aims to gather the information that can be the basis for the academic designer in local bamboo-based new products design engineering. The research was conducted using the qualitative method based on the interview with the craftsman, business, and multidisciplinary academia, supported by the literature study. The research concluded that the recent bamboo products design development in Sleman Regency needs to be directed to the type of product that complies with functional, uniqueness, and production efficiency aspects, especially in furniture, decoration, and interior/ exterior component products.
\end{abstract}

Key words: bamboo, product, design, industry

\begin{abstract}
Abstrak
Industri kerajinan bambu di Kabupaten Sleman belum mengalami pertumbuhan yang berarti dalam dekade terakhir ini. Para pelaku industri bambu berkeinginan untuk bisa bersinergi dengan akademisi dalam pengembangan desain. Konsep pengembangan desain produk tidak dapat terlepas dari terjadinya proses desain yang mengharuskan adanya tahapan penggalian informasi berbagai hal terkait produk agar karya desain yang dihasilkan bisa menjadi solusi masalah industrinya. Penelitian dasar ini bertujuan untuk mendapatkan beberapa informasi yang bisa menjadi landasan bagi desainer akademisi dalam merekayasa desain-desain produk baru berbasis bambu lokal. Penelitian dilakukan dengan metode kualitatif yang datanya digali melalui wawancara mendalam pada tiga sumber data yaitu perajin, pengusaha dan akademisi lintas disiplin, serta studi pustaka. Kesimpulan penelitian ini adalah bahwa pengembangan desain produk bambu di Kabupaten Sleman untuk saat ini perlu diarahkan pada jenis produk yang memenuhi aspek fungsional, keunikan, dan efisiensi proses produksi terutama pada produk mebel, elemen dekorasi, dan komponen interior/eksterior.
\end{abstract}

Kata kunci: bambu, produk, desain, industri

\section{Pendahuluan}

Industri mebel dan kerajinan bambu telah lama berkembang di wilayah Kabupaten Sleman. Perkembangannya sejak puluhan tahun yang lalu mengalami pasang surut dari waktu ke waktu dan pernah mencapai puncak kejayaannya pada seputar tahun 2000 bersamaan waktunya dengan perkembangan sektor kerajinan lain secara umum. Pada dekade terakhir ini industri bambu Kabupaten Sleman belum tumbuh secara signifikan, bahkan mengalami penurunan permintaan pasar. Menurut informasi yang diperoleh penulis masalah utama yang dihadapi para perajin adalah belum adanya desaindesain baru yang sesuai kebutuhan industri. Di sisi lain peluang produk berbahan dasar bambu di pasar internasional telah terbuka luas seiring menguatnya kesadaran masyarakat global untuk memakai produk ramah lingkungan. Kementerian Perdagangan RI (2011) menginformasikan beberapa negara tujuan produk ini adalah Amerika, Eropa, dan negara di kawasan Asia seperti Singapura, Jepang, Malaysia.

Situasi lemahnya daya saing produk kerajinan bambu dalam merespons peluang pasar ekspor telah

\footnotetext{
* Corresponding author Tel : +62-812-2736-427 ; e-mail : ismael_bidisi@yahoo.com
} 
mendorong munculnya keinginan kelompok perajin bersinergi dengan akademisi dalam pengembangan desain produk yang berbasis bambu lokal. Dalam konteks industri kreatif diharapkan sinergi ini akan dapat memperkuat tahapan proses kreasi dalam mendukung proses produksi dan meningkatkan daya tarik konsumen. Sebagaimana tertuang dalam konsep pengembangan kabupaten/kota kreatif Indonesia diperlukan adanya ekosistem pengembangan ekonomi kreatif yang mendorong adanya penguatan tahapan proses kreasi, produksi, distribusi, konsumsi dan konservasi (Badan Ekonomi Kreatif Indonesia, 2016).

Kota kreatif diidentikkan dengan 4 hal, yaitu infrastruktur budaya dan seni sebagai daya tariknya, adanya aktivitas ekonomi kreatif, masyarakat yang kreatif, dan sebagai habitat bagi pertumbuhan kultur kreativitas (Girard, Baycan, \& Nijkamp, 2011; Jayadi \& Prasetya, 2018). Oleh karena itu, peran pengembangan desain produk menjadi sangat penting. Tidak saja sebagai pendorong agar masyarakat menjadi semakin kreatif, juga dalam hal ini akan berkontribusi pada peningkatan dukungan proses produksi dan memotivasi masyarakat untuk meningkatkan konsumsi produk-produk berbasis bambu.

Konsep pengembangan desain produk tidak dapat terlepas dari terjadinya proses desain yang mengharuskan adanya tahapan penggalian informasi berbagai hal terkait produk agar karya desain yang dihasilkan bisa menjadi solusi masalah industrinya. Peran akademisi dalam sinergi pengembangan desain produk bambu perlu didukung berbagai informasi yang memungkinkan karya-karya desain yang dihasilkan relevan dengan peluang pasar dan dalam konteks yang kuat dengan ketersediaan sumberdaya di wilayah setempat seperti varietas bambu yang menjadi bahan baku serta sumberdaya manusia dan teknologi yang mendukung proses produksi. Oleh karenanya penelitian ini dilakukan untuk bisa menjawab permasalahan tentang ragam desain produk apa saja yang berpotensi untuk dikembangkan para pelaku industri bambu di Kabupaten Sleman.

Penelitian dasar ini bertujuan untuk mendapatkan beberapa informasi yang bisa menjadi landasan bagi desainer akademisi dalam merekayasa desain-desain produk baru berbasis bamboo. Selain itu, penelitian ini juga diharapkan dapat menyatukan visi berbagai pihak yang terlibat dalam upaya peningkatan kuantitas dan kualitas desain produk berbasis bambu. Selanjutnya hasil penelitian ini bisa mendukung pengembangan industri bambu di Kabupaten Sleman yang sejak tahun 2013 telah menetapkan bambu sebagai hasil hutan bukan kayu yang menjadi komoditas unggulan. Beberapa informasi yang diperoleh diharapkan bisa menjadi kontribusi bagi Pemerintah dalam membuat kebijakan dan programprogram pendampingan masyarakat perajin untuk memacu produktivitas industri kecil menengah dalam menghasilkan produk-produk kreatif berbahan dasar bambu.

\section{Bahan dan metode}

Budaya masyarakat Indonesia dalam menggunakan produk barang berbahan bambu terus mengalami perkembangan dan memerlukan edukasi yang lebih komprehensif tentang nilai plus pemanfaatan bambu dalam memenuhi aktivitas kehidupan sehari-hari. Seperti yang dikemukakan oleh Kementerian Perdagangan (2018) bahwa orang Indonesia sudah lama memanfaatkan bambu untuk bangunan rumah, perabotan, alat pertanian, kerajinan, alat musik, dan makanan. Namun bambu belum menjadi prioritas pengembangan dan masih dilihat sebagai bahan milik kaum miskin yang cepat rusak. Perlu ada pihak yang dapat memberi perhatian, baik kepada pengembangan perkebunan bambu, pengembangan usaha kerajinan bambu, serta pihak yang membantu mempromosikan produk bambu.

Pentingnya menggali potensi bambu sebagai kekayaan material lokal bagi masyarakat, terutama masyarakat Indonesia karena potensinya sangat menjanjikan untuk dimanfaatkan dalam kehidupan maupun dikembangkan sebagai produk industri. Dalam Arsad (2015) dikemukakan bahwa bambu merupakan tumbuhan yang mudah dikembangkan dan memiliki daur hidup relatif cepat, dengan waktu panen hanya 3-4 tahun. Bambu merupakan tumbuhan yang dapat dijadikan sebagai substitusi bahan baku kayu yang produksinya makin menurun dan harganya relatif mahal. Sedangkan bambu memiliki keunggulan tersendiri dibanding kayu karena bambu memiliki sifat ulet, elastisitas tinggi, mudah dibentuk dan harganya relatif murah. Bambu dapat direkayasa bentuk dan fungsinya dengan teknologi sederhana hingga teknologi tinggi.

Menurut Morisco (2006), berdasarkan pertumbuhannya bambu dapat dibedakan dalam dua kelompok besar yaitu bambu simpodial dan bambu monopodial. Bambu monopodial berkembang dengan rhizome yang menerobos ke berbagai arah di bawah tanah dan muncul ke permukaan tanah sebagai tegakan bambu yang individual. Sedangkan bambu simpodial tumbuh dalam bentuk rumpun, di mana setiap rhizome hanya akan menghasilkan satu batang bambu, dan bambu muda akan tumbuh mengelilingi bambu yang tua. Bambu jenis simpodial inilah yang 
tumbuh subur di daerah yang beriklim tropis dan subtropis.

Di Kabupaten Sleman tumbuh subur beberapa jenis bambu. Dalam penelitian yang dilakukan Prasetyawati (2016) dikemukakan Desa Sendang Rejo, Kecamatan Minggir merupakan salah satu daerah penghasil bambu di Kabupaten Sleman. Di desa tersebut terdapat tiga dusun dengan rumpunrumpun bambu hampir di setiap pekarangan rumah. Di desa Sendang Rejo ada 8 jenis bambu, yaitu Apus (G. apus (J.A. \& J.H. Schultes) Kurz), Wulung ( $G$. atroviolacea Widjaja), Legi (G. atter (Hassk.) Kurz), Petung (Dendrocalamus asper (Schultes f.) Backer ex Heyne), Ampel (Bambusa vulgaris Schrader ex Wendland), Uncue (Phyllostachys aurea Carr ex A. \& C. Riviere), Peting (G. levis (Blanco) Merril), dan Jepang (Thyrsostachys siamensis Gamble).

Beragamnya jenis bambu yang ada di wilayah Sleman selama ini belum dikelola secara maksimal pemanfaatannya sebagai produk industri yang memiliki potensi ekonomi tinggi karena keterbatasan desain produknya. Dalam penelitian yang dilakukan oleh Mulandari \& Budiani (2019) dikemukakan bahwa jenis produk kerajinan bambu di Kabupaten Sleman terdiri dari mebel bambu, gedek dan anyaman kepang, perabotan rumah tangga dari bambu, dan souvenir dari bambu. Jenis produksi kerajinan bambu yang paling banyak dihasilkan di Kabupaten Sleman adalah besek.

Desain produk mebel dan kerajinan bambu di Kabupaten Sleman perlu dikembangkan dengan dukungan teknologi yang lebih maju saat ini seperti metode laminated dan coiling. Menurut Minke (2012) metode laminated merupakan cara mengolah menggunakan mesin press untuk menyatukan bilahbilah bambu menjadi lembaran seperti papan kayu. Metode ini dimanfaatkan untuk kebutuhan furnitur, lantai dan produk yang memerlukan lembaran papan. Sedangkan metode coiling hampir sama dengan metode laminated menggunakan mesin press untuk menyatukan bambu dalam bentuk yang lebih fleksibel.

Dalam upaya peningkatan kuantitas dan kualitas produk ekspor Pemerintah Kabupaten Sleman perlu menerapkan strategi inovasi produk agar mampu bersaing di pasar global. Inovasi produk, oleh Dhewanto dkk. (2014) didefinisikan sebagai produk hasil dari pengembangan produk baru oleh suatu perusahaan atau industri, baik yang sudah ada maupun belum. Dari produk lama yang telah mencapai titik jenuh di pasaran, diperlukan sebuah inovasi untuk mengganti produk lama tersebut. Penggantian ini dapat berupa produk pengganti yang secara total baru atau dengan perkembangan produk lama yang lebih modern dan up to date, sehingga dapat terus meningkatkan keinginan konsumen dalam keputusan pembelian produk tersebut.

Metode penelitian yang digunakan untuk menjawab permasalahan tentang ragam desain produk apa saja yang berpotensi untuk dikembangkan para pelaku industri bambu di Kabupaten Sleman ini adalah adalah penelitian kualitatif. Metode kualitatif biasanya digunakan untuk menjawab berbagai persoalan tentang ciri-ciri fenomena yang dapat menggunakan beberapa metode (Sumartono, 2017). Penelitian kualitatif juga memiliki ciri ciri antara lain: deskriptif, eksploratif, komprehensif, kontekstual, dan induktif. Hal ini diperlukan agar peneliti mampu membaca konteks dari latar sosial, ekonomi dan budaya dari masyarakat serta pelaku industri kreatif di wilayah Kabupaten Sleman.

Informasi yang diperoleh dengan cara ini adalah perkembangan budaya masyarakat dalam merespons potensi bambu yang ada di wilayah seputarnya menjadi produk industri. Perkembangan ini terkait dengan potensi sumberdaya manusia yang terlibat dalam penerapan konsep pengembangan desain selanjutnya serta diidentifikasi desain produk apa saja yang berpotensi untuk dikembangkan para pelaku industri mebel dan kerajinan bambu di sentra industri setempat. Data lain yang dikumpulkan dalam penelitian ini adalah identifikasi jenis-jenis bambu, perkembangan teknologi pengolahan bambu, permintaan pasar produk bambu baik lokal maupun ekspor, serta pengamatan tentang perkembangan dan trend desain yang terkait dengan pengembangan desain produk bambu.

Penelitian ini dikerjakan dengan instrumen utamanya adalah peneliti sendiri dengan bersikap terbuka dan menyesuaikan diri dengan kondisi dan situasi yang ditemukan di lapangan. Pengumpulan dilakukan dengan teknik wawancara mendalam (indepth interview) pada tiga sumber data yaitu perajin, eksportir dan akademisi, serta analisis dokumen atau arsip (content analysis). Wawancara dilakukan pada narasumber yang dipilih sebagai purposive sample karena dipandang lebih mampu memberikan kelengkapan dan kedalaman data agar bisa menghasilkan informasi untuk kajian lanjut penelitian dasar ini ke tahap penelitian terapan yang menghasilkan prototipe desain-desain produk bambu.

\section{Hasil dan pembahasan}

Bambu sebagai material alam semakin disukai oleh masyarakat lokal dan global seiring dengan makin 
kuatnya pasokan produk berbahan dasar plastik. Di beberapa wilayah Indonesia bahan bambu telah dikreasi masyarakat dalam beragam produk untuk memenuhi kebutuhan hidup sehari-hari, baik sebagai peralatan makan, hiasan rumah, maupun konstruksi bangunan.

Saat ini telah berkembang beragam desain produk yang beredar sebagai komoditas perdagangan mebel dan barang kerajinan skala internasional. Secara garis besar barang-barang tersebut dapat diklasifikasi ke dalam beberapa fungsi yang berbeda, yaitu: (1) Produk anyaman berbentuk keranjang dengan beragam bentuknya; (2) Peralatan makan seperti sendok, garpu, gelas, dan lain-lain; (3) Furnitur untuk pemakaian dalam ruang dan ruang luar; (4) Dekorasi interior seperti lampu meja, lampu dinding, panel pameran, dan lain-lain; (5) Komponen arsitektur seperti genteng, panel pagar, konstruksi bangunan; dan (6) Produk kreatif lainnya seperti sepeda, alat musik, dan lain-lain.

Gambaran tentang proporsi produk bambu yang diperdagangkan di pasar lokal dan di pasar internasional terutama Jepang, Asia, Amerika, Eropa adalah $60 \%$ produk mebel seperti meja kursi untuk ruang dalam maupun ruang luar, $20 \%$ Produk alat rumah tangga seperti piring, sendok, mangkok dll. serta produk yang berbahan limbah bambu seperti bingkai foto dan dekorasi ruang, dan 20\% Produk komponen bangunan seperti panel pameran, bahan lantai, pagar dll.

Produk berbasis bambu lainnya yang saat ini berkembang pesat di pasar internasional adalah tekstil bambu, tetapi produk ini membutuhkan teknologi produksi yang saat ini belum dimiliki oleh masyarakat industri bambu di Indonesia, khususnya Kabupaten Sleman. Proses pengawetan bambu yang perlu mendapat perhatian adalah proses pengawetan bagi bambu yang karakteristiknya kuat, dan proses pembuburan bagi bambu yang tidak layak dikonstruksi. Kalangan pengusaha, terutama produk ekspor, cenderung menghindari penggunaan bahan finishing bambu seperti vernish yang selama ini banyak digunakan oleh para perajin karena menjadi nilai minus bagi pasar internasional.

\section{Karakter jenis-jenis bambu untuk produk mebel dan kerajinan}

Untuk memahami manfaat material bambu sebagai salah satu alternatif elemen bangunan perlu dilakukan analisa sifat fisik dan mekanik bambu. Sifat fisik terdiri dari kerapatan kadar air dan berat jenis sedangkan sifat mekanik terdiri dari kuat tekan, kuat lentur, kuat geser dan kuat tarik. Bambu merupakan jenis tanaman rumput berkayu yang berbentuk pohon atau perdu. Berat jenis dan kerapatan bambu menentukan sifat fisika dan mekanikanya. Berat jenis bambu berkisar antara 0,5 - 0,9 gram $/ \mathrm{cm}^{3}$. Bambu jenis tertentu mempunyai perbandingan kekuatan dan berat yang tinggi sehingga dapat dimanfaatkan sebagai bahan bangunan maupun mebel dan kerajinan. Kandungan air pada serat bambu sangat berpengaruh pada kekuatan bambu, sehingga perlu perhatian yang cermat pada sifat kembang susutnya yang bisa menyebabkan bangunan mengalami perubahan bentuk dan penurunan kualitas akibat adanya penyusutan.

Bambu adalah kelompok tanaman tingkat tinggi dari keluarga Poaceae yang dapat tumbuh hingga 60 $\mathrm{cm}$ per hari. Jenis bambu di Indonesia diperkirakan ada sekitar 159 spesies dari 1250 spesies bambu yang ada di dunia. Beberapa jenis tanaman bambu yang banyak tumbuh dan bisa dibudidaya di wilayah Kabupaten Sleman beserta pemanfaatannya yaitu: (1) Bambu Ampel (Bambusa vulgaris) untuk bahan baku kertas, bahan bangunan; (2) Bambu Apus (Gigantochloa apus) untuk kandang burung, produk anyaman, peralatan rumah tangga dan konstruksi ringan; (3) Bambu Ater/Legi (Gigantochloa atter) untuk bahan bangunan dan kerajinan; (4) Bambu Betung (Dendrocalamus asper) untuk produk mebel dan konstruksi bangunan; dan (5) Bambu Wulung (Gigantochloa atroviolacea) untuk produk mebel, barang dekoratif, kerajinan tangan, pembuatan alat musik, dan panel pagar.

Mebel dan kerajinan bambu merupakan komoditas yang banyak diproduksi untuk pemenuhan pasar ekspor, terutama untuk tujuan negara Jepang, Italia, Jerman dan Hungaria. Permasalahan yang banyak dihadapi industri kerajinan bambu, khususnya anyaman, adalah terbatasnya peralatan seperti alat irat dan laminasi. Kondisi ini sangat terasa terutama di level industri kecil dan menengah yang mengakibatkna kapasitas produksi sulit ditingkatkan memenuhi permintaan pasar. Hal ini mendorong terjadinya perubahan permintaan pasar dari komoditas produk kerajinan menjadi produk elemen bangunan yang mudah dikerjakan dengan peralatan sederhana.

Laboratorium Alih Teknologi dan Inkubasi, Balai Besar Kerajinan dan Batik (BBKB) Yogyakarta telah menginisiasi pembuatan mesin irat bambu yang terjangkau oleh industri kecil dan menengah. Kegiatan pengembangan yang dilakukan telah menghasilkan mesin irat bambu dengan spesifikasi penggerak berupa motor listrik 1 phase, $220 \mathrm{~V}, 1 / 3$ $\mathrm{HP}, 1430 \mathrm{rpm}$. Mesin tersebut memiliki dimensi panjang $73 \mathrm{~cm}$, lebar $29 \mathrm{~cm}$, tinggi $78 \mathrm{~cm}$, berat 90 kg. Kapasitas dari mesin irat bambu tersebut tertera dalam Tabel 1. 
Tabel 1. Kapasitas mesin irat bambu BBKB Yogyakarta

\begin{tabular}{cc}
\hline Panjang iratan $(\mathrm{cm})$ & Kapasitas (iratan/jam) \\
\hline 30 & 2693 \\
\hline 40 & 2464 \\
\hline 50 & 2207 \\
\hline 60 & 1902 \\
\hline
\end{tabular}

Teknologi produksi yang diterapkan pada industri bambu di Kabupaten Sleman adalah laminasi. Proses pengolahan bahan bambu betung menjadi produk papan laminasi adalah sebagai berikut: (1) Proses pengawetan secara alami dan ditiriskan selama 2 (dua) bulan; (2) Potong sesuai modul yang diperlukan, antara lain: $180 \mathrm{~cm}, 200 \mathrm{~cm}, 220 \mathrm{~cm}$; (3) Potongan yang masih bulat dibelah menjadi bilahbilah selebar $3 \mathrm{~cm}$; (4) Bambu bilah dikuliti untuk diambil dagingnya: dan (5) Penyatuan bilah-bilah bambu dengan lem dan dipres menjadi bidang/batang.

\section{Sinergi akademisi dalam pengembangan desain produk bambu}

Sleman memiliki potensi sumberdaya manusia perajin yang berlimpah, tersebar di sebelas sentra kerajinan bambu di wilayah Kabupaten Sleman. Produk yang dihasilkan para perajin bambu cukup beragam antara lain, mebel, kerajinan anyaman dan lain-lain. Beberapa perajin telah memiliki pasar ekspor yang secara kontinyu menyerap aneka produk berbahan baku bambu.

Problem yang dihadapi dalam industri bambu di Kabupaten Sleman antara lain kapasitas produksi yang rendah. Sentra kerajinan seringkali tidak mampu merespons permintaan pasar ekspor dalam jumlah besar karena keterbatasan kapasitas produksi. Hal ini disebabkan oleh teknologi produksi yang belum bisa memproses produk bambu secara efisien, dan juga desain-desain produk yang dimiliki tidak bisa diaplikasikan untuk produk massal. Teknologi produksi yang diterapkan saat ini juga masih tertinggal dibanding beberapa negara Asia lain yang sudah serba mekanis mulai dari pembahanan hingga finishing, sementara para perajin Sleman masih serba manual dalam proses produksinya.

Berbagai persoalan yang dihadapi dalam pengembangan industri bambu Sleman diyakini bisa diatasi melalui upaya perbaikan situasi dan kondisi yang didukung oleh berbagai elemen, salah satunya adalah membangun sinergi pengembangan industri bambu dengan melibatkan akademisi. Beberapa hal yang bisa dilakukan oleh akademisi antara lain: (1) Akademisi perlu memiliki wawasan trend desain yang mampu menembus pasar global dan memiliki insight bahwa produk bambu itu prospektif; (2) Mahasiswa dan dosen yang terlibat dalam pengembangan desain produk bambu sangat perlu memiliki pengetahuan yang komprehensif tentang bambu, antara lain karakteristik bambu, proses penebangan, pengawetan, pencapaian bentuk, dan teknologi produksi. Dengan bekal pengetahuan tersebut desainer diharapkan akan bisa menghasilkan karya desain yang aplikatif dan dapat diproduksi secara efisien dengan teknologi yang ada; dan (3) Proposisi nilai: akademisi perlu berperan dalam membangun citra produk berbasis bambu sebagai barang konsumsi yang bernilai tinggi, sehingga desain-desain yang dikembangkan dapat diarahkan untuk menembus pasar segmen menengah ke atas.

\section{Kesimpulan}

Pemerintah Kabupaten Sleman sedang mengupayakan produk bambu dapat menjadi komoditas unggulan dan menjadikan Sleman sebagai sentra industri bambu yang memiliki nilai strategis untuk meningkatkan kesejahteraan masyarakat. Dalam konteks ekonomi kreatif pengembangan industri memerlukan adanya ekosistem yang mendukung tahapan proses kreasi, produksi, distribusi, konsumsi dan konservasi. Sehingga perlu ada sinergi antara desainer akademisi dengan dunia industri yang bermanfaat memperkuat tahapan proses kreasi dalam mendukung proses produksi dan meningkatkan daya tarik konsumen.

Kabupaten Sleman memiliki potensi sumberdaya yang cukup besar untuk pengembangan industri produk bambu yang dapat dirinci sebagai berikut:

a.Potensi sumberdaya alam yang berupa tanaman bambu yang tumbuh subur di banyak lokasi wilayah Kabupaten Sleman dan terdiri dari jenis tanaman bambu ampel, apus, ater/legi, betung, wulung.

b.Potensi sumberdaya manusia ada di 11 sentra industri bambu Sleman yang beranggotakan 1500 perajin bambu dengan kemampuan memproduksi aneka produk berbahan dasar bambu.

c. Potensi teknologi produksi yang berkembang saat ini adalah teknik laminasi yang dapat menghasilkan bambu olahan untuk diterapkan pada berbagai jenis produk kreatif untuk merespons permintaan pasar ekspor.

d.Desain produk bambu yang potensial dikembangkan oleh para desainer dapat diklasifikasikan sebagai berikut: (1) Produk mebel seperti meja kursi untuk ruang dalam dan ruang luar; (2) Produk alat rumah tangga seperti piring, sendok, mangkok, serta produk yang berbahan 
limbah bambu seperti bingkai foto dan dekorasi; dan (3) Produk komponen interior atau bangunan seperti panel pameran, bahan lantai, pagar dan lainlain.

Dalam melakukan kreasi dan inovasi produk berbasis bambu desainer perlu mempertimbangkan aspek fungsi produk, keunikan desain, efisiensi proses produksi, dan trend desain yang berkembang di pasar lokal dan internasional terutama Jepang, Asia, Amerika, Eropa.

\section{Daftar pustaka}

Arsad, E. (2015). Teknologi pengolahan dan manfaat bambu. Jurnal Riset Industri Hasil Hutan, 7(1), 45-52.

Badan Ekonomi Kreatif Indonesia. (2016). Sistem Ekonomi Kreatif Nasional: Panduan Pemeringkatan Kabupaten/Kota Kreatif. Jakarta: Badan Ekonomi Kreatif Indonesia

Dhewanto, W., Hendrati D. M., Anggraeni P., Grisna A., \& Ameka, I. (2014). Manajemen Inovasi: Peluang Sukses Menghadapi Perubahan. Yogyakarta: Penerbit Andi
Jayadi, N., \& Prasetya, R. D. (2018). Penguatan eksistensi kota kreatif melalui inovasi desain kamuflase menara BTS berbasis zonasi wilayah. Productum: Jurnal Desain Produk (Pengetahuan dan Perancangan Produk), 3(3), 101-106.

Girard, L. F., Baycan, T., \& Nijkamp, P. (2011). Sustainable city and creativity. Burlington: Ashgate Publishing Company.

Kementerian Perdagangan. (2011). Warta Ekspor Edisi November 2011. Jakarta: Kementerian Perdagangan Republik Indonesia

Kementerian Perdagangan. (2018). Warta Ekspor Edisi Desember 2018. Jakarta: Kementerian Perdagangan Republik Indonesia

Minke, G. (2012). Building with bamboo: design and technology of a sustainable architecture. Walter de Gruyter

Morisco. (2006). Teknologi Bambu. Bahan Kuliah Magister Teknologi Bahan Bangunan. Yogyakarta: Program Studi Teknik Sipil Universitas Gadjah Mada

Mulandari, H., \& Budiani, S. R. (2019). Pola pemasaran industri kerajinan bambu di Kabupaten Sleman. Jurnal Geografi: Volume 11 Nomor 2 Tahun 2019, 86

Prasetyawati, Y. (2016). Jenis, Sebaran dan Potensi Bambu di Desa Sendang Rejo, Kecamatan Minggir, Sleman (Doctoral dissertation, Universitas Gadjah Mada) 